\title{
Incremental Changes Are not Enough - Voting Rights Are a Matter of Democratic Principle
}

\author{
Tony Venables
}

It is encouraging to note that the 'Let me vote' European Citizens Initiative is attracting much support. As much has already been said and commented upon, I will limit my contribution to just a few additional points.

1. This initiative launched by Philippe Cayla has my full support and I will sign it. As many have already pointed out, it has been successful in opening a debate around an issue that has been overlooked for too long. More importantly however it has also encouraged the EU institutions to start thinking about citizenship as a developmental or evolutionary concept. So far, there has been an apparent reluctance to use Article 25 of the Treaty on the Functioning of the European Union, which allows introducing additional rights of EU citizens. The fact that this initiative has successfully been registered with the Commission on 1 June 2012 will push citizenship forward beyond the present confines of the Treaties.

2. Secondly, I believe that the right to vote is so fundamental to democracy that any arguments reflecting the difficulties of putting it into effect pale into insignificance. It is simply unacceptable that the 12 million citizens who make full use of their right to move freely around the EU should have to put up with not having their say in their host country. Moreover, an important percentage of these not only do not gain a right to vote, but also lose their voice in their country of origin (here it would be interesting to know just how many are in this situation). Therefore, if one accepts that democracy is based on fundamental principles, it is not possible to claim that the denial of voting rights does not hinder free movement of citizens. Past contributions in this forum have already identified the existing difficulties in gaining voting rights and have also outlined different approaches to solving this problem, which are not necessarily mutually exclusive. What is important is first of all to grant the right to vote to those citizens who have but a partial or no say at all in regional and national elections. Questions around how and when to do this are secondary issues. Indeed, some solutions as to how to make this change have already been proposed in this forum but there are many others. During several citizens' panels organised in the framework 
of ECAS projects, it was argued that many European citizens would consider using an EU card which would - among other uses to facilitate free movement - allow them to vote in specific elections. This proposition of course raises many issues of data protection but shows that there is a strong desire to counter these practical difficulties.

3. Concerns around timing have been expressed, namely that it may be too early to implement such a change and that it would be rather more beneficial to concentrate on improving the implementation and exercise of existing rights. This is often a very valid argument as civil society organisations, politicians and the EU Institutions tend to create new rights and legislation for their own credit rather than enforcing present ones. Such considerations, however, do not apply here. Launching this debate for the individuals who have no right to vote in their host country will also draw attention to the fact that they have an underused right - that is the right to vote in local and EU elections. It is increasingly apparent that those who have no say at national level lose their interest in political involvement, as they feel sidelined. Indeed, it is perhaps too easily forgotten that an ECI such as this one must be seen, first and foremost, from the very basic perspective of the citizen entitled to sign it. Their lack of participation in European elections in particular has a detrimental effect on citizenship, which is not to be ignored at a time when citizens' attachment to the EU is in decline. According to Eurobarometer, the past couple of years have seen a noticeable 5 per cent decline of citizens who believe that membership of their country in the EU is a 'good thing'. An incremental approach to European citizenship can work, for example in the case of social rights and entitlements, but it is certainly more questionable in the area of political rights where the contradictions are too apparent and become disincentives.

4. The European Citizen Action Service (ECAS) has been much involved in supporting ECIs having set up several support systems, organised many awareness raising events and disseminated information to ECI initiators and organisers. Presently it is also working on setting up an Online Signature Collection system, which will meet the specified requirements of the European Commission and provide organisers with a secure server. Philippe Cayla has accepted a real challenge, as any ECI which deals with citizenship will by its very nature encounter many difficulties. Indeed, as this debate has shown, intra-EU migration is extremely complex both legislatively and pragmatically. One key obstacle will also arise during signature collection due to the scattered geographical distribution of those most likely to sign it. Increasing evidence here at ECAS has also shown that social media offer no 
shortcut for this complex and bureaucratic procedure of collecting signatures. It will be no easy task, but given that the ECI will inevitably encounter considerable obstacles, we must do everything to ensure its success. Citizenship needs civil society.

Open Access This chapter is licensed under the terms of the Creative Commons Attribution 4.0 International License (http://creativecommons.org/licenses/by/4.0/), which permits use, sharing, adaptation, distribution and reproduction in any medium or format, as long as you give appropriate credit to the original author(s) and the source, provide a link to the Creative Commons license and indicate if changes were made.

The images or other third party material in this chapter are included in the chapter's Creative Commons license, unless indicated otherwise in a credit line to the material. If material is not included in the chapter's Creative Commons license and your intended use is not permitted by statutory regulation or exceeds the permitted use, you will need to obtain permission directly from the copyright holder. 